\title{
LIQUID LOW-LEVEL WASTE GENERATION \\ PROJECTIONS FOR ORNL IN 1993
}

S. M. DePaoli

Date Published: April 1994

Prepared by

OAK RIDGE NATIONAL LABORATORY

Oak Ridge, Tennessee 37831-6285

managed by

MARTIN MARIETTA ENERGY SYSTEMS, INC.

for the

U.S. DEPARTMENT OF ENERGY

under contract DE-AC05-84OR21400

MASTR

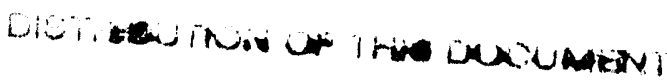




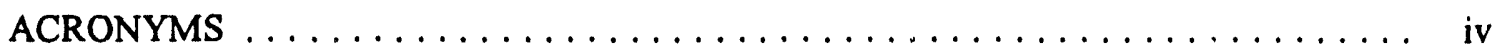

LIST OF TABLES $\ldots \ldots \ldots \ldots \ldots \ldots \ldots \ldots \ldots \ldots \ldots \ldots \ldots$

LIST OF FIGURES $\ldots \ldots \ldots \ldots \ldots \ldots \ldots \ldots \ldots \ldots \ldots \ldots \ldots \ldots \ldots$

EXECUTIVE SUMMARY $\ldots \ldots \ldots \ldots \ldots \ldots \ldots \ldots \ldots \ldots \ldots \ldots \ldots \ldots \ldots \ldots$

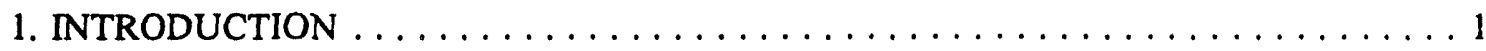

2. BACKGROUND $\ldots \ldots \ldots \ldots \ldots \ldots \ldots \ldots \ldots \ldots \ldots \ldots \ldots \ldots \ldots \ldots \ldots \ldots$

3. LIQUID LOW-LEVEL WASTE GENERATION $\ldots \ldots \ldots \ldots \ldots \ldots \ldots \ldots \ldots$

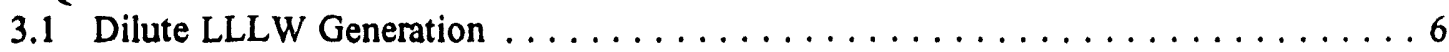

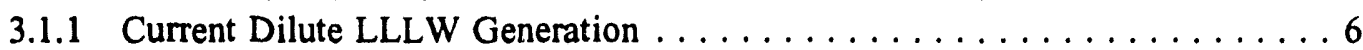

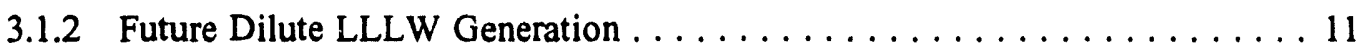

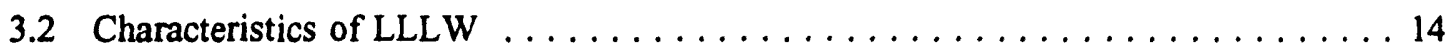

3.2.1 Current LLLW Characteristics . . . . . . . . . . . . . . . . . 14

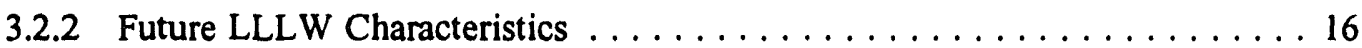

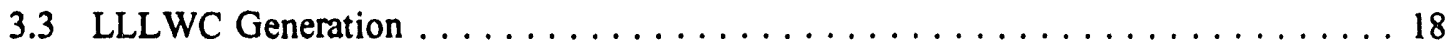

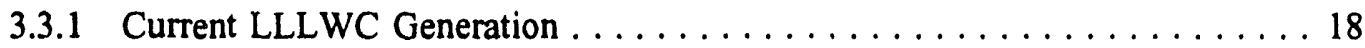

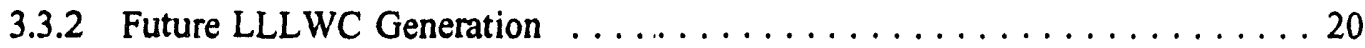

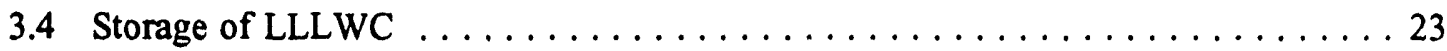

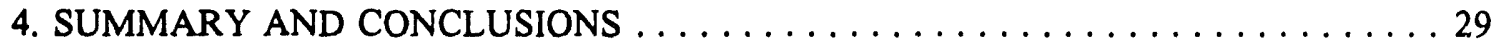

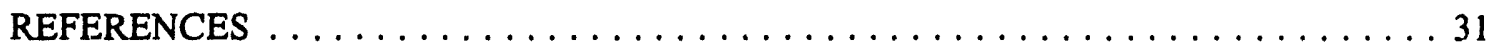




\section{ACRONYMS}

$\begin{array}{ll}\text { BSR } & \text { Bulk Shielding Reactor } \\ \text { CY } & \text { Calendax Year } \\ \text { D \& D } & \text { decontamination and decommissioning } \\ \text { DOE } & \text { U.S. Department of Energy } \\ \text { ERP } & \text { Environmental Restoration Program } \\ \text { FFA } & \text { Federal Facilities Agreement } \\ \text { HFIR } & \text { High Flux Isotope Reactor } \\ \text { HOG } & \text { hot off-gas } \\ \text { ISP } & \text { Isotopes Shutdown Plan } \\ \text { ITE } & \text { in-tank evaporation } \\ \text { IX } & \text { ion exchange } \\ \text { LITR } & \text { Low-Intensity Test Reactor } \\ \text { LLLW } & \text { liquid low-level waste } \\ \text { LLLWC } & \text { liquid low-level waste concentrate } \\ \text { LLW } & \text { low-level waste } \\ \text { MVST } & \text { Melton Valley Storage Tank } \\ \text { NTF } & \text { North Tank Farm } \\ \text { OGR } & \text { Old Graphite Reactor } \\ \text { ORNL } & \text { Oak Ridge National Laboratory } \\ \text { ORR } & \text { Oak Ridge Research Reactor } \\ \text { OSR } & \text { Operation Safety Report } \\ \text { OTE } & \text { out-of-tank evaporation } \\ \text { PWTP } & \text { Process Waste Treatment Plant } \\ \text { R \& D } & \text { research and development } \\ \text { RA } & \text { Remedial Actions } \\ \text { REDC } & \text { Radiochemical Engineering Development Center } \\ \text { SC } & \text { solidification campaign } \\ \text { STF } & \text { South Tank Farm } \\ \text { TRU } & \text { transuranic } \\ \text { VOG } & \text { vessel off-gas } \\ \text { VRF } & \text { volume reduction factor } \\ \text { WAG } & \text { Waste Area Grouping } \\ & \end{array}$




\section{LIST OF TABLES}

1. Historical and present dilute liquid low-level waste generation, $1990-1993 \ldots \ldots \ldots 7$

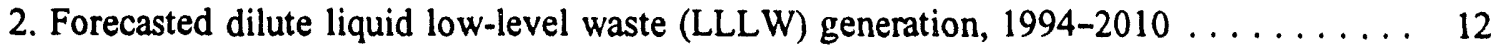

3. Estimated isotopes and amounts in liquid low-level waste generated for CY $1993 \ldots 15$

4. Contaminants disposed of via the liquid low-level waste system, in $1993 \ldots \ldots \ldots$

5. Liquid low-level waste concentrate (LLLWC) generation during 1992 and $1993 \ldots 19$

6. Forecasted liquid low-level waste concentrate (LLLWC), $1994-2010 \ldots \ldots \ldots \ldots \ldots 21$

7. Profile of liquid low-level waste concentrate (LLLWC) storage needs and

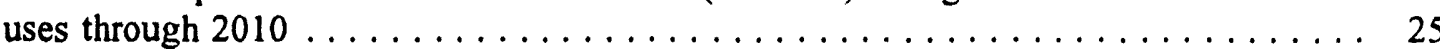

\section{LIST OF FIGURES}

1. Schematic of the liquid low-level waste system $\ldots \ldots \ldots \ldots \ldots \ldots \ldots \ldots \ldots$

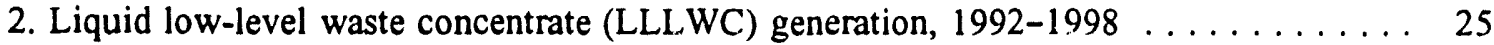

3. Liquid low-level waste concentrate (LLLWC) generation, $1996-2010 \ldots \ldots \ldots \ldots .26$

4. Liquid low-level waste concentrate (LLLWC) generation, 1996-2010 without (a) source treatment at HFIR and (b) the PWTP upgrade 


\section{EXECUTTVE SUMMARY}

Liquid low-level waste (LLLW) is generated by various programs and projects throughout Oak Ridge National Laboratory (ORNL). These wastes are collected in underground collection tanks, bottles, and trucks; they are then neutralized with sodium hydroxide and treated for volume reduction at the ORNL evaporator facility. This report presents historical and projected data concerning the volume and characterization of

LLLW, prior to and after evaporation. Storage space for projected waste generation is also discussed. 


\section{INTRODUCTION}

The Waste Management and Remedial Actions Division operates the Oak Ridge National Laboratory (ORNL) liquid low-level waste (LLLW) system, which collects highly radioactive wastewaters produced by reactor operations, research and development (R\&D) operations, Environmental Restoration Program activities, and waste operations activities. An ongoing effort to develop and implement improved liquid processing systems has been under way with the following objectives: (1) to provide facilities to treat all present and future wastewaters generated at ORNL, (2) to meet applicable regulatory requirements, and (3) to improve effluent quality while reducing the amount of secondary waste generated. Efforts began in the mid-1980s to develop a consistent, logical approach for upgrading the low-level waste (LLW) system to meet these objectives. A strategy was developed for upgrading the LLLW system, R\&D programs and technical assessments were initiated to support these plans, and capital projects were implemented to perform the planned upgrades. This report was written to support the LLLW management strategy by reflecting evaluations of current and future waste characterization/generation data, changes in interagency agreements and regulations, and advances in the $R \& D$ program to treat LLLW.

\section{BACKGROUND}

LLLW has been generated at ORNL since the inception of laboratory operations in the 1940s. This type of waste is collected in underground storage tanks, is often neutralized with sodium hydroxide, and is jetted or pumped to the central LLLW system where it is concentrated by evaporation. The liquid LLW concentrate (LLLWC), which is removed as bottoms from the evaporators, is transferred to tanks for storage where it 
separates into sludge and supernate phases. This waste is stored in these phases until further processing steps render it suitable for disposal.

From 1964 to 1984, the LLLWC was stirred into a homogeneous mixture, mixed with grout, and disposed of underground via hydrofracturing. Since the discontinuation of hydrofracturing in 1984, LLLWC has accumulated in the LLLW evaporator service tanks (ESTs) and the Melton Valley Storage Tanks (MVSTs), which have a limited storage capacity. A diagram of the liquid waste system is shown in Figure 1.

In 1987, a planning team was established to develop a strateg; for the disposal of the LLLWC stored since the shutdown of the hydrofracture disposal facility. The recommended action plan contained near-, intermediate-, and long-term treatment plans. ${ }^{1}$

The near-term management plan for treatment of LLLWC consisted of three phases: (1) reduction of wastes generated by identifying and evaluating LLLW sources and treatment systems, (2) removal of excess water from the stored waste by in-tank evaporation (ITE) in the MVSTs, and (3) solidification MVST supernatant in a concrete matrix to provide operational flexibility of the current LLLW system. The intermediateterm management plan for LLLWC was to process existing transuranic waste sludge and the associated supernatant for disposal at the Waste Isolation Pilot Plant, the deep geologic repository that the U.S. Department of Energy (DOE) is establishing as the disposal site for all DOE-generated TRU waste. The long-term management plan recommended the development of a treatment flowsheet which would produce a solid waste form for on-site disposal of newly generated LLLWC and minimize the production of TRU waste and other solid waste requiring off-site disposal. Significant accomplishments and changes have occurred since the planning team's strategy was developed. The near-term strategy plans are progressing very effectively. However, delays 


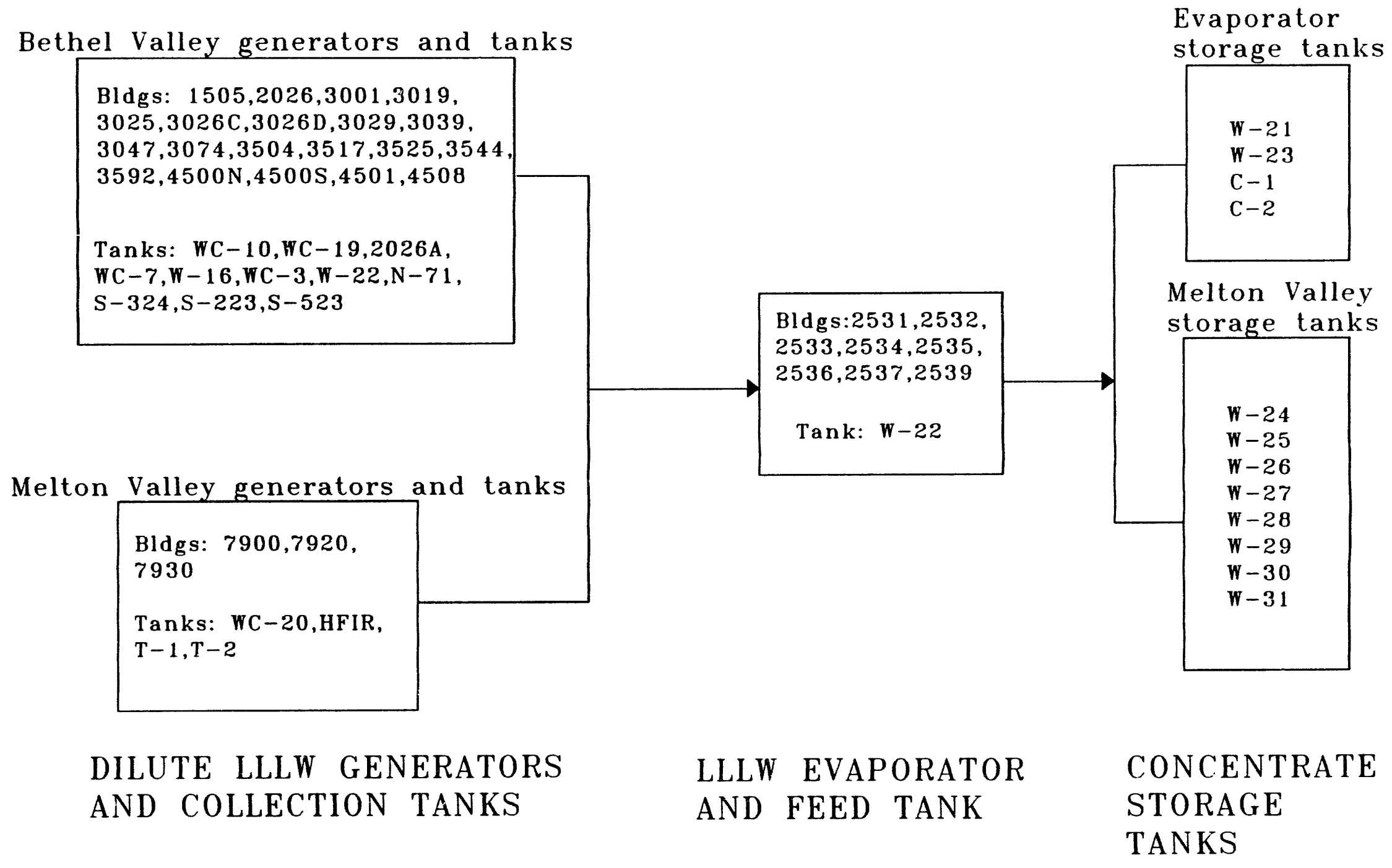

Fig. 1. Schematic of the liquid low-level waste system. 
in capital projects and some increases in waste generation warranted an increase in storage space in the near term. The sources of LLLWC have been extensively identified and source treatment options are being developed for the largest generators of LLLWC. ITE has been operating successfully for just over 1 year; approximately 21,700 gal of water has been evaporated from the MVSTs during that year. Two solidification campaigns have been successfully completed. Approximately 95,000 gal of supernate was solidified in these two campaigns. A third campaign began in November 1993 to solidify 50,000 gal of LLLWC. Six new 100,000-gal tanks are scheduled to be installed toward the end of the 1990s.

In terms of intermediate and long-term plans for the LLLW system, programs are in place to perform R\&D work to define flowsheets for processing LLLWC. Implementation of Land Disposal Restrictions for Resource Conservation and Recovery Act waste has required that the research concerning long-term treatment options for newly generated waste be accelerated. This research is occurring in conjunction with development of Waste Handling and Packaging Plant.

A previous report summarizes LLLW generation up to $1989 .^{2}$ This report will summarize generation of LLLW over the last few years and will discuss projected generation rates over the next 15 years. Operations to reduce LLLWC over the last few years will be discussed, as will the plans currently being developed that will be put into place in the near future to reduce LLLW generation and activity. 


\section{LIQUID I OW-LEVEL WASTE GENERATION}

This document reports on the ongoing review of the ORNL liquid waste system to identify waste generators and analyze the current LLLW system operation. Many changes have taken place in the use and operation of the LLLW system over the last few years. Significant changes in the use of the LLLW system include (1) the shutdown of the isotope production programs, (2) the shutdown of the Oak Ridge Research Reactor (ORR) and Bulk Shielding Reactor (BSR), and (3) the restart of the High Flux Isotope Reactor (HFIR). In terms of the operation of the LLLW system, the Federal Facilities Agreement (FFA) took effect in January 1992, shutting down several active LLLW tanks. The generators that had previously used those tanks began bottling LLLW. Those tanks are now collecting only nonprogrammatic waste (filter-pit inleakage, sumps, etc.). In the next several years, many operation modifications are expected to reduce the generation of LLLW. The Process Waste Treatment Plant (PWTP) upgrades, source treatment at HFIR, possible source treatment at the Radiochemical Engineering Development Center (REDC), and rerouting of some nonprogrammatic waste streams will all have a significant impact on the LLLW system operation.

Information to support the analysis of LLLW dilute and concentrate generation has been obtained over the last 5 years through "generator surveys." Through these surveys, information has been accumulated on (1) the programs and activities which generate LLLW, (2) estimates on dilute LLLW volume, (3) radioactivity of the waste, and (4) solids contents of the waste (caustic, cleaners, etc.). This information has been used to predict dilute and concentrate generation rates for each generator, concentrate storage volume needs, and future waste profiles. The following sections summarize the information 
received this calendar year, as well as the forecasted changes to this information as currently envisioned.

\subsection{DILUTE LLLW GENERATION}

\subsubsection{Current Dilute LLLW Generation}

Table 1 presents the historical dilute LLLW generation from 1990 through 1992, as well as the expected generation for 1993 (based on collection rates through October 1993 and the 1993 generator surveys). Total dilute LLLW generation has not changed significantly during the last 4 years; however, generation rates at several facilities have decreased or increased over the last few years. Among those rates that have changed are the following:

WC-10 - (Bldgs. 3029, 3030, 3031, 3038W, 3047): An estimated 176 gal/month ( $2200 \mathrm{gal} / \mathrm{yr}$ ) will be generated in the ongoing surveillance and maintenance of these facilities. During 1992, only Bldgs. 3029 and 3047 were generating LLLW, at an estimated $250 \mathrm{gal} / \mathrm{month}$ (3000 gal/yr). However, during 1993, all the facilities listed above will be using hot drains in ongoing surveillance and maintenance activities but at a lower overall rate. Heavy decontamination of the facilities as part of the Isotopes Shutdown Plan (ISP) is on hold until funding becomes available, which will probably not occur until after 1997.

WC-19 - (Old Graphite Reactor/ORR/BSR): The ORR and BSR have stopped generating LLLW temporarily. Both facilities are regenerating the reactor pool waters by taking a bleed stream from the pool while feeding in a deionized water 
Table 1. Historical and present dilute liquid low-level waste generation, 1990-1993

\begin{tabular}{|c|c|c|c|c|c|}
\hline \multirow[b]{2}{*}{ Tank } & \multirow[b]{2}{*}{ Building } & \multicolumn{4}{|c|}{ Dilute LLLW generation (gal/year) } \\
\hline & & 1990 & 1991 & 1992 & $1993^{\circ}$ \\
\hline & \multicolumn{5}{|c|}{ Generaters } \\
\hline WC-10 & $3028,3029^{\bullet}, 3030-32,3038,3039,3047^{\star}, 3093$ & 1,800 & 4,800 & 3,000 & 2,200 \\
\hline WC-19 & Bldgs. $3001^{\circ}$ (OGR), 3042(ORR), 3119(BSR) & 10,600 & 10,600 & 4,000 & 1,200 \\
\hline 2026 & Bldg. 2026 & 1,400 & 3,400 & 2,700 & 3,600 \\
\hline WC-11 & Bldg. $4501,4505,4507,4500 \mathrm{~N}$ & 200 & 600 & 0 & 0 \\
\hline WC- 12 & Bldg. 4505 & $\mathbf{0}$ & 0 & $\mathbf{0}$ & 0 \\
\hline WC-13 & Bldgs. 4500N\&S, 4507, 4508 & 600 & 70 & 0 & 0 \\
\hline WC-14 & Bldg. 4501 & 200 & 600 & 0 & 0 \\
\hline W-12 & Bldg. 3525 & 17.700 & 12,330 & 0 & 0 \\
\hline WC-20 & Bldg. $7920^{*}, 7930$ (REDC) & 12,800 & 17,150 & 13,000 & 11,000 \\
\hline HFIR & Bldg. $7900^{\circ}$ (HFIR) & 48,100 & 99,400 & 121,400 & 110,000 \\
\hline WC-586 & Eldgs. $3508,3541,3592$ & 0 & o & 0 & $\mathbf{0}$ \\
\hline WC-7 & Bldg. $3504^{\circ}$ & 450 & 2,200 & 530 & 120 \\
\hline WC-8 & Bldg. 3503 & 0 & 0 & 0 & 0 \\
\hline$W \cdot 16$ & Bldg. 3026D & 140 & 2,000 & 550 & 500 \\
\hline$W \cdot 17 \& 18$ & Bldg. 3026C & 1200 & 1,200 & 0 & 0 \\
\hline WC-3 & Bldg. $3025^{\circ}$ & 12 & 250 & 420 & 200 \\
\hline WC-2 & Bldg. 3028,3038 & 0 & 0 & 0 & 0 \\
\hline \multirow[t]{2}{*}{ W-22 } & PWTP Feed* & 3,700 & 7,400 & 12,600 & 10,800 \\
\hline & 3039 Stack & 42,300 & 42,000 & 38,900 & 43,200 \\
\hline N-71 & Bldg. $3019^{\circ}$ & 1,200 & 1,000 & 360 & 150 \\
\hline$S-324,223,523$ & Bldg. $3517^{\circ}$ & 4,800 & 0 & 400 & 0 \\
\hline \multirow{2}{*}{ Trucked } & Bldg. $3074^{*}$ & 1,300 & 1,700 & 1,900 & 1,700 \\
\hline & Bldg. 3525* & & & 1,300 & 1,700 \\
\hline \multirow[t]{10}{*}{ Bottled } & Bldg. $3026 C^{\circ}$ & & & & 12 \\
\hline & Bldg. 3047" & & & & 12 \\
\hline & Bldg. $3592^{*}$ & & & 50 & 96 \\
\hline & Bldg. $4500 N^{*}$ & & & 6 & 12 \\
\hline & Bldg. $4500 S^{\bullet}$ & & & & 12 \\
\hline & Bldg. $4501^{*}$ & & & & 12 \\
\hline & Bldg. $4508^{\circ}$ & & & & 12 \\
\hline & Bldg. 1505* & & & & 36 \\
\hline & SUBTOTAL & 148,502 & 206,700 & 204,116 & 186,574 \\
\hline & \multicolumn{5}{|c|}{ Sumps, fliter pits, other nonprogrammatic warte and inleaknge } \\
\hline WC-10 & Various HOG pots in Isotope Area & 5,300 & 17,700 & 9,200 & 11,900 \\
\hline WC-19 & Bldg. 3042 HOG pot & 18,600 & 9,200 & 3,000 & 1,000 \\
\hline$W-1 A$ & Inleakage & 46,600 & 38.800 & 21,000 & 17,000 \\
\hline WC-11 & Bldg. 4556 (filter pit), $4500 \mathrm{~N}$ west wing sump & 4,100 & 20,100 & 5,600 & 4,800 \\
\hline WC-12 & Tank T.30 sump & 1,100 & 700 & 700 & 400 \\
\hline WC-13 & Inleakage & 2,500 & 920 & 840 & 100 \\
\hline WC.14 & Bldg. 4501 sumps & 400 & 70 & 160 & 400 \\
\hline WC-8 & Pump prime water & 14,220 & 4,300 & 1,400 & 1,400 \\
\hline WC-9 & HOG pot & 10,570 & 18,600 & 7,760 & 10,000 \\
\hline WC-5\&6 & Inleakage & 4,130 & 3,500 & 2.650 & 2.000 \\
\hline$W-12$ & Inleakage & 3,000 & 3,000 & 2,950 & 3,300 \\
\hline HFIR & Bldgs. 7911, 7913, 7922 (Stack, filter pit, etc.) & 26,000 & 26,000 & 26,000 & 26,000 \\
\hline WC-2 & Isotope HOG pot, 3039 HOG pot & 240 & 240 & 300 & 300 \\
\hline WC-7 & Inleakage & 330 & 2,100 & 410 & 400 \\
\hline$W-17 \& 18$ & Inleakage & 30,400 & 29,400 & 9,670 & 11,500 \\
\hline S-523, 223, 324 & Bldg. 3517 filter pit, HOG pot & 8.000 & 22,800 & 9,300 & 33,000 \\
\hline WC-3 & Bldg. 3098 (filter pit) & 100 & 100 & 100 & 100 \\
\hline \multirow[t]{4}{*}{ W-16 } & Seal traps for W.16, 17, 18,Bldg.3515 & 200 & 200 & 200 & 100 \\
\hline & SUBTOTAL & 175,790 & 197,730 & 101,240 & 123,700 \\
\hline & Other (surnps, etc.) ${ }^{b}$ & 81,100 & 139,150 & 78,000 & 95,000 \\
\hline & TOTAL & 405,392 & 543,580 & 397,628 & 405,274 \\
\hline
\end{tabular}

OGR = Old Graphite Reactor; ORR - Oak Ridge Research Reactor; BSR - Bulk Shielding Reactor; REDC - Radiochemical Engineering Development Center; HFIR - High Flux Isotope Reactor; PWTP - Process Warte Treatment Plant; HOG - hot off-gas

- These facilities are currently generating LLLW (as of 1993). Facilities that do not have an asterisk are not currently generating LLLW. Data for 1993 estimated based on 1993 generator surveys and information available January - October, 1993 from Waste Management.

Includes Bldgs. 2531, 2533, 2534, 7830, inactive tanks, etc. 
stream for replacement water, rather than the customary regeneration which produces LLLW. A 1992 General Plant Project is being implemented to make this a permanent arrangement. However, LLLW will possibly be generated before the permanent arrangement is implemented if some problems are encountered in reaching a steady state. A reduction of approximately 1000 gal/year dilute LLLW has been accomplished through these upgrades (6000-7000 gal/year if the reactors were operating). LLLW collection at WC-19 is down significantly from 1992. Regeneration of the demineralizer columns in Bldg. 3001, the Old Graphite Reactor (OGR), is ongoing. Regeneration of the columns at OGR results in approximately $1200 \mathrm{gal} / \mathrm{yr}$ of dilute LLLW.

S-324, 223, 523 - (Bldg. 3517): The large increase in volume for 1993 is due entirely to rainfall variation. While 1992 was a very dry year, early 1993 experienced extremely heavy rainfall. The filter pits were jetted many times early in 1993 . No decontamination activities have been performed during 1993 at Bldg. 3517.

WC-20 - (REDC): Although a small change in volume is expected for 1993 ( $<1000$ gal/year over the previous year), the waste stream composition has changed significantly. The REDC off-gas scrubber (VOG) solution was changed from 4-5 $M$ potassium hydroxide to $2.2 \mathrm{M}$ sodium hydroxide, thus greatly reducing the potassium salts entering the LLLW system. Removal of potassium is desirable because potassium competes with cesium removal in most treatment processes. This change has also reduced the amount of dissolved solids in the LLLW. Because the volumereduction capability of the LLLW evaporators is a function of the dissolved solids, this resulted in a lower production of concentrate for this facility. An estimated 50- 
9

$65 \%$ reduction in concentrate generation at $\mathrm{REDC}$ has been realized by eliminating the potassium and reducing the dissolved solids content in the VOG system.

REDC personnel are working on other waste minimization projects, some to reduce the activity as well as the volumes, but reduction estimates cannot be made at the present time.

HFIR: HFIR generation has remained approximately the same for CY1993 as compared with generation estimates for 1992; however, problems associated with the resin in the demineralizer columns have increased the number of regenerations performed over the past few years. A generation of 120,000 gal was reported for last year (1992) and approximately 120,000 gal of dilute LLLW is expected to be generated during 1993 , although through October 1993 that yearly average is 110,000 gal.

W-12 - (Bldg. 3525): All waste generated at Bldg. 3525 is now collected in tank F-501 and trucked from there to the LLLW system. The estimate for 1993 is 1700 $\mathrm{gal} / \mathrm{yr}$ (higher than the 1992 generation). This increase is due to more decontamination of cells and an increase in the work level at the facility.

WC-3 - (Bldg. 3025): The 1993 generator estimate from Bldg. 3025 is 1700 gal/yr. This is a conservative estimate, and to date the generation is only approximately 200 gal/yr. The projected increase is due to a projected increase in research activities involving metal polishing; however, the change in generation rates has yet to be 
realized. Bldg. 3098, the Filter Facility for the BSR and the Low-Intensity Test Reactor (LITR) also discharges an estimated $100 \mathrm{gal} / \mathrm{yr}$ to this tank.

Bottled waste - (Chemistry Division, Chemical Technology Division, Health and Safety Research Division, Environmental Sciences Division, Metals and Ceramics Division): A total of $204 \mathrm{gal} / \mathrm{yr}$ of dilute LLLW is estimated to be bottled by the listed divisions for CY 1993.

Inactive tanks - (7562, 3001-B, 3013, H-209): Several inactive tanks will possibly be emptied to the LLLW system in 1993 . Approximately 5500 gal of dilute LLLW would be generated. Through June 1993, only contents of tank 7562 were sent to the LLLW system (5000 gal by tanker truck). The contents of a few of these tanks may be sent to the PWTP.

Trucked waste - (Bldgs. 3074, 7830): The Manipulator Repair Facility (Bldg. 3074) is estimating a generation rate of $382 \mathrm{gal} /$ month which is identical to the 1992 estimate. Approximately $1000 \mathrm{gal} / \mathrm{month}$ is trucked from the MVST sumps at Bldg. 7830.

Other generation - (Bldg. 2531): An estimated $2000 \mathrm{gal} / \mathrm{month}$ of dilute LLLW is collected and sent to W-22 from the Evaporator Complex Facility filter pits and sumps. (This volume is included in the "Other" grouping under the "Sumps, filter pits, other nonprogrammatic waste and inleakage" subheading in Table 1.) 
The major dilute LLLW generators for 1993 are as follows: HFIR (30\%), the 3039 stack (9\%), REDC (2\%), and the PWTP (2\%); all others account for $4 \%$ of the dilute LLLW. Nonprogrammatic waste and inleakage account for the other $53 \%$ of dilute LLLW generation during 1993.

\subsubsection{Future Dilute LLLW Generation}

Several changes are expected in dilute LLLW generation over the next 15 years. Forecasted dilute LLLW generation rates are listed in Table 2. Included are generation rates of LLLW for decontamination and decommissioning (D\&D) activities by the Surplus Facilities Program, as well as Remedial Actions (RA) activities which mainly consider the cleanup and remediation of Waste Area Grouping (WAG) sites. In both cases, the LLLW to be generated is a result of decontamination activities. The transfer of inactive tank supernates will be a major source of dilute LLLW during 1997 and 1998 when the South Tank Farm is expected to be remediated. The following paragraphs summarize changes in LLLW generation expected by the current generators.

Tank WC-10 is serving only to maintain and eventually to decontaminate the Isotope Facilities. The shutdown of these facilities is dependent on budgeting concerns for the ISP. Currently, the funding for shutdown is not expected to become available until 1998; thereafter, shutdown is expected to take approximately 4 years to complete. The availability of WC-10 for this whole period is unknown; however, for purposes of projections, it is assumed that the tank will be available.

Tank WC-19 is currently receiving waste only from the regeneration of ion exchange columns at the ORR. This is expected to occur for 3-4 more years, until the required 
Table 2. Forecasted dilute liquid low-level waste generation, 1994-2010

\begin{tabular}{|c|c|c|c|c|c|c|c|c|c|c|c|c|c|c|c|c|c|}
\hline \multirow[b]{2}{*}{ Tent (Fecility) } & \multicolumn{17}{|c|}{ Dilure LLLW generzation (galyear) } \\
\hline & 1994 & 1995 & 1996 & 1997 & 1998 & 1999 & 2000 & 2001 & 2002 & 2003 & 2004 & 2005 & 2006 & 2007 & 2008 & 2009 & 2010 \\
\hline \multicolumn{18}{|c|}{ Generators } \\
\hline WC-10 (Isolope Area) & 2,200 & 2,200 & 2,200 & 2,200 & 12,000 & 12,000 & 12,000 & 12,000 & 2,200 & 2,200 & 2,200 & 2,200 & 2,200 & 2,200 & 2,200 & 2,200 & 2,200 \\
\hline WC-19 (Rescions) & 1200 & 1,200 & 1,200 & 1,200 & 0 & 0 & 0 & 0 & 0 & 0 & 0 & 0 & 0 & 0 & $\mathbf{0}$ & 0 & 0 \\
\hline 2026 (Bldg. 2026) & 2,700 & 2,700 & 2,700 & 2,700 & 2,700 & 2,700 & 2,700 & 2,700 & 2,700 & 2,700 & 2,700 & 2.700 & 2,700 & 2,700 & 2,700 & 2,700 & 2,700 \\
\hline WC-20 (REDC) & 12,000 & 12,000 & 12,000 & 12,000 & 12,000 & 12,000 & 12,000 & 12,000 & 12,000 & 12,000 & 12,000 & 12,000 & 12,000 & 12,000 & 12,000 & 12,000 & 12,000 \\
\hline HFIR & 120,000 & 120,000 & 120,000 & 120,000 & 0 & 0 & 0 & 0 & 0 & 0 & 0 & 0 & 0 & 0 & 0 & 0 & 0 \\
\hline WC-7 (Bldg. 3504) & 120 & 10 & 10 & 10 & 10 & 10 & 10 & 10 & 10 & 10 & 10 & 10 & 10 & 10 & 10 & 10 & 10 \\
\hline W.16 (BVAg. 3026D) & 900 & 900 & 0 & 0 & 0 & 0 & 0 & 0 & 0 & 0 & 0 & 0 & 0 & 0 & 0 & 0 & 0 \\
\hline WC-3 (Bldg. 3025) & 1,700 & 1,700 & 1,700 & 1,700 & 1,700 & 1,700 & 1,700 & 1,700 & 1,700 & 1,700 & 1,700 & 1,700 & 1,700 & 1,700 & 1,700 & 1,700 & 1,700 \\
\hline W-22 (PWTP feod) & 10,800 & 0 & 0 & 0 & 0 & 0 & 0 & 0 & 0 & 0 & 0 & 0 & 0 & 0 & 0 & 0 & 0 \\
\hline (3039 Sunc) & 43,200 & 43,200 & 43,200 & 43,200 & 43,200 & 43,200 & 43,200 & 43,200 & 43,200 & 43,200 & 43,200 & 43,200 & 43200 & 43,200 & 43,200 & 432200 & 43200 \\
\hline N-71 (Blag. 3019) & 300 & 300 & 300 & 300 & 300 & 300 & 300 & 300 & 300 & 300 & 300 & 300 & 300 & 300 & 300 & 300 & 300 \\
\hline S-523 (Bldg. 3517) & 400 & 100 & 400 & 400 & 4,000 & 4,000 & 4,000 & 4,000 & 0 & 0 & 0 & 0 & 0 & 0 & 0 & 0 & 0 \\
\hline Trucked (Bdag. 3074) & 1,700 & 1,700 & 1,700 & 1,700 & 1,700 & 1,700 & 1.700 & 1,700 & 1,700 & 1,700 & 1,700 & 1,700 & 1,700 & 1,700 & 1,700 & 1,700 & 1,700 \\
\hline (Bldg. 3525) & 4,800 & 4,800 & 4,800 & 4,800 & 4,800 & 4,800 & 4,800 & 4,800 & 4,800 & 4,800 & 4,800 & 4,800 & 4,800 & 4,800 & 4,800 & 4,800 & 4,800 \\
\hline Botrled (various) & 200 & 200 & 200 & 200 & 200 & 200 & 200 & 200 & 200 & 200 & 200 & 200 & 200 & 200 & 200 & 200 & 200 \\
\hline SUBTOTAL & 202,220 & 191.310 & 190,410 & 190,410 & 82,610 & $\mathbf{2 2 . 6 1 0}$ & 82,610 & $\mathbf{8 2 . 6 1 0}$ & 68,810 & 68.810 & 68,810 & 68.810 & $\cos 210$ & 68,810 & cos,210 & cos,810 & $\cos 810$ \\
\hline \multicolumn{18}{|c|}{ Others } \\
\hline Nonprogrammatic waste & 215,000 & 215,000 & 215,000 & 215,000 & 215,000 & 185,000 & 185,000 & 185,000 & 185,000 & 185,000 & 185,000 & 185,000 & 185,000 & 185,000 & 185,000 & 185,000 & 185,000 \\
\hline Imactive Tenks" & 109,300 & 0 & & 276,000 & 100,300 & 0 & & 0 & 0 & 0 & 0 & 0 & 0 & 0 & 0 & 25,50 & $\begin{array}{r}0 \\
7788\end{array}$ \\
\hline DeD Activities & 2,350 & 0 & 11,244 & $\begin{array}{r}41,584 \\
169510\end{array}$ & $\begin{array}{r}56,326 \\
105,585\end{array}$ & $\begin{array}{r}81,457 \\
108,817\end{array}$ & $\begin{array}{r}62,278 \\
110,592\end{array}$ & $\begin{array}{l}127,204 \\
110,594\end{array}$ & $\begin{array}{l}72,432 \\
41,606\end{array}$ & $\begin{array}{l}72,638 \\
46,992\end{array}$ & $\begin{array}{l}64,925 \\
59,877\end{array}$ & $\begin{array}{r}140,456 \\
47,186\end{array}$ & $\begin{array}{r}140,456 \\
34,243\end{array}$ & $\begin{array}{r}140,456 \\
34,243\end{array}$ & $\begin{array}{l}75,531 \\
33,918\end{array}$ & $\begin{array}{l}75,531 \\
33,573\end{array}$ & $\begin{array}{l}77,138 \\
23,664\end{array}$ \\
\hline SUBTTOTAL & 437,052 & 344,848 & 357,504 & 702,094 & 477.211 & 375,274 & 357,870 & 422.798 & 299.038 & 304,630 & 309,802 & 372,642 & 359,699 & 359.699 & 294,449 & 294,104 & 205,822 \\
\hline TOTAL & 639,272 & 536,198 & 547,914 & 892,504 & 559821 & 457,884 & 440,480 & ses,408 & 367,848 & 373,440 & 378,612 & 441,452 & 42aseses & 428:5es & 363.259 & 362.914 & 354,632 \\
\hline
\end{tabular}

REDC = Radiochemical Engineering Development Center; HFIR = High Flux Isotope Reactor; PWTP = Process Waste Treatment Plant; D\&D = decontamination and decommissioning; $\mathrm{RA}=$ Remedial Actions.

${ }^{a}$ Nonprogrammatic waste refers to inleakage, collection in hot off-gas pots, stacks, etc. throughout the active LLLW system.

${ }^{b}$ The remediation of the inactive LLLW tanks is expected to generate these volumes of dilute LLLW by transfer of supernate only to the active LLLW system. 
decontamination work in that facility is completed. The time frame for this work is dependent on budget concerns and would change if funding were not forthcoming.

The PWTP dilute "feed" stream will be eliminated. Currently, a portion of the regeneration solution at the PWTP is sent to the LLLW system for evaporation (the "PWTP feed" stream) because of the limited capacity of the PWTP evaporator. An upgrade at the PWTP will enable the whole stream to be evaporated on-site, thus eliminating the "PWTP feed" stream to the LLLW system around CY 1995. The "PWTP concentrate" stream will increase somewhat, but an overall waste reduction for the PWTP will be realized (see Sect. 3.3.2).

Tank WC-7 will be shut down in 1994, and Bldg. 3504 will bottle the LLLW. Waste generation at Bldg. 3504 will probably decrease somewhat when this occurs.

LLLW at HFIR will be eliminated when the resin currently used in the demineralizer ion exchange columns is disposed of as a solid waste rather than being regenerated. The time frame for this upgrade is about 1997.

Waste generation at Bldg. 3026D is projected to cease in CY 1995. Liquid waste generated during the past few years at Bldg. 3026D has been the result of cleanup and decontamination activities. The final cleanup and decontamination of the facility is dependent on budget concerns and availability and is therefore subject to change depending on the procurement of these funds. The availability of tank W-16 during this whole period is unknown; however, for projection purposes, it is assumed the tank will be available.

REDC is researching various techniques for the removal of TRU elements from its waste stream, although the volume is not expected to decrease much in the next several 
years. Significant strides in volume reduction have occurred in the previous few years at REDC (see Sect. 3.1.1, "WC-20-REDC").

Forecasts for generation of LLLW by the D\&D projects and RA activities at ORNL have been incorporated in the projections in this report for planning purposes. The majority of this waste will not be generated until after 2000. In addition, the LLLW generated through these programs will be decontamination liquids and will likely have large volume reduction factors (VRFs).

For the rest of the facilities, generation rates have been kept constant for the 19942010 time frame for projection purposes. These estimates are certain to change as time progresses.

\subsection{CHARACTERISTICS OF LLLW}

\subsubsection{Current LLLW Characteristics}

Generators are asked to report also on the radioactive contents of the liquid waste in the LLLW surveys. Table 3 summarizes the current findings on radioactive species being disposed of through the LLLW system as reported in the surveys. The curie quantities given in Table 3 are estimates, because actual sample analyses are not made. REDC contributes the majority of the radioactivity in the currently generated LLLW and will continue to contribute significantly to the total activity of the waste.

Other contaminants (such as cleaners, acids, caustics, and salts used and disposed of by the facility) determine the amount of LLLWC generated. In addition, caustic is added to many of the tanks when they are jetted or pumped to the central LLLW system for evaporation. This also adds to the concentrate produced. Most facilities use nitric acid, sodium hydroxide, and cleaners such as Ajax and Mr. Clean when regenerating columns 
Table 3. Estimated isotopes and amounts in liquid low-level waste generated during CY1993

\begin{tabular}{|c|c|c|}
\hline Isotope $(\mathbf{s})^{a}$ & $\begin{array}{l}\text { Estimated } \\
\text { quantity } \\
\text { (Ci/year) } \\
\end{array}$ & Facility \\
\hline${ }^{3} \mathrm{H}$ & 4 & $\begin{array}{l}\text { High Flux Isotope Reactor (HFIR) (>99\%); } \\
\text { Bldgs. 3026C, 4500S, 1505; Waste Area } \\
\text { Grouping (WAG) } 5\end{array}$ \\
\hline${ }^{14} \mathrm{C}$ & 0.14 & Bldg. 4500S (>99\%); Bldgs. 4500N, 3504 \\
\hline${ }^{54} \mathrm{Mn}$ & 0.33 & $\begin{array}{l}\text { HFIR (91\%); Bldg. } 3025 \text { (9\%); Bldgs. 4508, } \\
\text { 3026D, 4500S }\end{array}$ \\
\hline${ }^{60} \mathrm{Co}$ & 10.82 & $\begin{array}{l}\text { HFIR ( } 88 \%) \text {; Bldg. } 3029 \text { (11\%); Bldgs. } 3047 \text {, } \\
4500 \text { S, 4508, 3025, 3026D, 1505, 3001, 3504; } \\
\text { WAG 5 }\end{array}$ \\
\hline${ }^{90} \mathrm{Sr}$ & 1 & $\begin{array}{l}\text { Bldg. } 3029 \text { (>99\%); Bldgs. } 3541,3019,4500 \text { S, } \\
\text { 1505, 3504; WAG } 5 \text { (see MFP also) }\end{array}$ \\
\hline${ }^{131} \mathbf{I}$ & 0.4 & HFIR (>99\%); Bldg. 3047 \\
\hline${ }^{137} \mathrm{Cs}$ & 1.13 & $\begin{array}{l}\text { Bldg. } 3029(88 \%) \text {; Bldg. } 3001(7 \%) \text {; Bldgs. } \\
4501,3019,4500 N, 4500 \text { S, } 3074,1505 ; \text { WAG } \\
5 \text { (see MFP also) }\end{array}$ \\
\hline${ }^{152,153.154} \mathrm{Eu}$ & 0.16 & $\begin{array}{l}\text { Bldg. } 3001 \text { (>99\%); Bldgs 3047, } 3031 \text { (see } \\
\text { MFP also) }\end{array}$ \\
\hline${ }^{12} \mathrm{Ir}$ & 13 & $\begin{array}{l}\text { Bldg. } 3525 \text { (77\%); Bldg. } 3029 \text { (23\%); Bldgs. } \\
\text { 3026C, } 3047\end{array}$ \\
\hline${ }^{241} \mathrm{Am}$ & 2.16 & Bldg. 7920 (>99\%); Bldgs. 4500S, 3504, 5505 \\
\hline $\begin{array}{l}\text { MFP (mixed } \\
\text { fission products) }\end{array}$ & 10,050 & Bldg. 7920 (>99\%); Bldg. 3525 \\
\hline
\end{tabular}

${ }^{a}$ Other isotopes reported in trace quantities include: ${ }^{55} \mathrm{Fe},{ }^{59} \mathrm{Fe},{ }^{85} \mathrm{Sr},{ }^{99} \mathrm{Tc},{ }^{103} \mathrm{Pd},{ }^{125} \mathrm{I},{ }^{134} \mathrm{Cs},{ }^{153} \mathrm{Gd},{ }^{188} \mathrm{Re}$, ${ }^{188} \mathrm{~W},{ }^{191} \mathrm{Os},{ }^{232} \mathrm{Th},{ }^{233} \mathrm{U},{ }^{235} \mathrm{U},{ }^{238} \mathrm{U}$.

${ }^{b}$ Mixed fission products include ${ }^{137} \mathrm{Cs},{ }^{134} \mathrm{Cs}$, ${ }^{90} \mathrm{Sr}$, and ${ }^{152,154,155} \mathrm{Eu}$. 
and decontaminating hot cells. The amount of these products used by the facility determines the VRF which will be realized when processed through the LLLW evaporator. This VRF is used in calculating the volume of LLLWC generated by the facility. Table 4 lists the major contaminants in the LLLW generated during CY 1993 as estimated in the LLLW surveys.

\subsubsection{Future LLLW Characteristics}

Information on the changes in the radioactivity of LLLW streams during the next 15 years is not easily estimated. The following occurrences are expected to have an impact on the radioactivity of the LLLW, the extent of which is given, if known:

(1) HFIR conversion of LLLW to solid LLW will remove the majority of ${ }^{3} \mathrm{H},{ }^{54} \mathrm{Mn}$, ${ }^{60} \mathrm{Co}$, and ${ }^{131} \mathrm{I}$ from the waste. Current planning projects that this will occur in 1998 and beyond.

(2) The ISP will generate a significant amount of radioactivity from a broad spectrum of isotopes, including most of those listed in Table 3 (especially ${ }^{90} \mathrm{Sr}$ and ${ }^{137} \mathrm{Cs}$, which would figure prominently in the cleanup of Building 3517).

(3) REDC source treatment, if implemented, would reduce the activity of its waste stream, especially the TRU content.

Changes in the quantities of nonradioactive contaminants in the LLLW are summarized below.

(1) HFIR conversion of LLLW to solid LLW will result in a large decrease in $\mathrm{NaOH}$ and $\mathrm{HNO}_{3}$ quantities.

(2) PWTP conversion of LLLW to solid LLW will result in a large decrease in $\mathrm{NaOH}$ and $\mathrm{HNO}_{3}$ quantities. 


\section{7}

\begin{tabular}{|c|c|c|c|}
\hline \multirow{2}{*}{$\begin{array}{c}\text { Oiher } \\
\text { contaminants }\end{array}$} & \multirow[b]{2}{*}{ Facllity } & \multicolumn{2}{|c|}{ Quantity } \\
\hline & & (g/year) & (lb/year) \\
\hline 40 S' Cleaner & Bldg. 3525 & $\frac{200}{3600}$ & 7.9 \\
\hline (NI14)2CO3 & Bldg. 3592 & 240 & 0.5 \\
\hline Triaberm cleaner & Bldg. 2026 & 90,909 & 200.0 \\
\hline SrClesCl & Bldg. 4500 N, E-28 & 1 & $<1.0$ \\
\hline Oxalic acid & Bldg. 3047 & 65,455 & 144.0 \\
\hline $\mathrm{NH} 4 \mathrm{OH}$ & Bldg. 4501 & 416 & 0.9 \\
\hline \multirow[t]{10}{*}{$\mathrm{NaOH}$} & Bldg. 7920 & 108,500 & 238.7 \\
\hline & Bldg. 7900 & $5,850,000$ & $12,870.0$ \\
\hline & Bldg. 4501 & 9,652 & 21.2 \\
\hline & Bldg. 4500 N, E-28 & 4 & $<1.0$ \\
\hline & Bldg. 3592 & 240 & 0.5 \\
\hline & Bldg. 3544 & $4,300,000$ & $9,460.0$ \\
\hline & Bldg. 3525 & 7570 & 16.7 \\
\hline & Bldg. 3039 & 88,400 & 194.5 \\
\hline & Bldg. 3001 & 9.700 & 21.3 \\
\hline & added to tanks & 462,166 & $1,016.8$ \\
\hline \multirow[t]{2}{*}{$\mathrm{NaNO} 3$} & Bldg. 7920 & 520,500 & $1,145.1$ \\
\hline & Bldg. 4500 N, E-28 & 286 & 0.6 \\
\hline $\mathrm{NaNO}_{2}$ & Bldg. 4501 & 2,350 & 5.2 \\
\hline \multirow[t]{2}{*}{$\mathrm{Na} \mathrm{HCO}_{3}$} & Bldg. 4500 N, E-28 & 323 & 0.7 \\
\hline & Bldg. 3592 & 3,000 & 6.6 \\
\hline NaDithionite & Bldg. 3592 & 50 & 0.1 \\
\hline \multirow[t]{2}{*}{$\mathrm{NaCl}$} & Bldg. 7920 & 108,500 & 238.7 \\
\hline & Bldg. 4500 N, E-28 & 436 & 1.0 \\
\hline NaCituate & Bldg. 3592 & 134 & 0.3 \\
\hline $\mathrm{NaAlO}_{2}$ & Bldg. 7920 & 110,000 & 242.0 \\
\hline $\mathrm{N}_{22} \mathrm{SO}_{4}$ & Bldg. 3592 & 720 & 1.6 \\
\hline \multirow[t]{3}{*}{$\mathrm{Na2} 2 \mathrm{CO} 3$} & Bldg. 7920 & 108,500 & 238.7 \\
\hline & Bldg. 4500 N, E-28 & 89 & 0.2 \\
\hline & Bldg. 3592 & 1,200 & 2.6 \\
\hline \multirow[t]{5}{*}{ Mr. Clean } & Bldg. 3525 & 4,542 & 10.0 \\
\hline & Bldg. 3074 & 41.635 & 91.6 \\
\hline & Bldg. 3029 & 8,327 & 18.3 \\
\hline & Bldg. 3026D & 4,164 & 9.2 \\
\hline & Bldg. 3025 & 912 & 2.0 \\
\hline $\mathrm{LiCl}$ & Bldg. 7920 & 68,000 & 149.6 \\
\hline KNO3 & Bldg. 4500 N, E-28 & 11 & $<1.0$ \\
\hline \multirow[t]{2}{*}{$\mathrm{KMnO4}$} & Bldg. 3592 & 960 & 2.1 \\
\hline & Bldg. 3047 & 54,545 & 120.0 \\
\hline $\mathbf{K C l}$ & Bldg 4500 N, E-28 & 8 & $<1.0$ \\
\hline \multirow[t]{12}{*}{ HNO3 } & Bldg. 7900 & $2,930,000$ & 6.446 .0 \\
\hline & Bldg. 5505 & 3407 & 7.5 \\
\hline & Bldg. $4500 \mathrm{~S}$ & 100 & 0.2 \\
\hline & Bldg. 3592 & 1,645 & 3.6 \\
\hline & Bldg. 3544 & $5,790,000$ & $12,738.0$ \\
\hline & Bldg. 3525 & 9,538 & 21.0 \\
\hline & Bldg. 3047 & 22,680 & 49.9 \\
\hline & Bldg. 3029 & 4770 & 10.5 \\
\hline & Bldg. 3025 & 2520 & 5.5 \\
\hline & Bldg. 3019 & 4,700 & 10.3 \\
\hline & Bldg 3001 & 8,600 & 18.9 \\
\hline & Bldg. 2026 & 457,834 & $1,007.2$ \\
\hline \multirow[t]{2}{*}{$\mathrm{H} 2 \mathrm{SO}_{4}$} & Bldg. 4508 & 371 & 0.8 \\
\hline & Bldg. 3025 & 2,138 & 4.7 \\
\hline Fantastic & Bldg. $3026 \mathrm{C}$ & 1,249 & 2.7 \\
\hline \multirow[t]{2}{*}{ Citric acid } & Bldg. 3592 & 50 & 0.1 \\
\hline & Bldg. 3047 & 21,818 & 48.0 \\
\hline A.jax & Bldg. 3047 & 87,200 & 191.8 \\
\hline & Bldg. $3026 \mathrm{C}$ & 1,249 & 2.7 \\
\hline Adogen $\cdot \mathrm{HCl}$ & Bldg. 7920 & 8,000 & 17.6 \\
\hline Abrasives & Bldg. 3025 & 3,750 & 8.3 \\
\hline HDEHP & Bldg. 7920 & 89,000 & 195.8 \\
\hline $\mathrm{HCl}$ & Bldg. 7920 & 100,000 & 220.0 \\
\hline & Bldg. 3525 & 4,835 & 10.6 \\
\hline A.cetic acid & Bldg. 4508 & 2271 & 5.0 \\
\hline Perchloric acid & Bldg. 4508 & 58 & 0.1 \\
\hline Total: & & $21,593,828$ & $47,498.4$ \\
\hline
\end{tabular}


(3) The ISP, when implemented, will result in an increase of $\mathrm{HNO}_{3}$, oxalic acid, and cleaners used in decontaminating hot cells and glove boxes (Mr. Clean, Ajax, etc.).

\subsection{LLLWC GENERATION}

\subsubsection{Current LLLWC Generation}

Three of the four largest dilute generators are the major sources of LLLW concentrate: the PWTP, HFIR, and REDC. Approximately $65 \%$ of the concentrate produced during 1992 was attributed to operations at the PWTP. HFIR operations generated an estimated 16\%, and REDC generated 12\% of the LLLWC during 1992. These estimates were based on generator survey information. Table 5 summarizes the concentrate generated during 1992 and the expected generation during 1993.

The actual rate of concentrate generation appears to be rather high during the first six months of 1993 (15,500 gal in 6 months); however, during 1991 and 1992, more than $65 \%$ of the concentrate produced for the year was generated in the first six months, so one might expect the generation rate to slow during the second half of this year. Generator estimates, as well as Waste Management records, show that HFIR generation has been up significantly during this 6-month period also. In addition, the frequency of regeneration at HFIR is up, resulting in a projected increase in concentrate generation by HFIR. Most of the increase in total LLLWC generation is likely attributable to this fact.

Approximately $26,000 \mathrm{gal}$ of concentrate is expected to be generated during 1993 based solely on the extrapolation of the amount of LLLWC that has been generated through July of this year. This LLLWC volume is $30 \%$ higher than the amount predicted by the generator surveys for this year. Based on generator estimates, the PWTP is 
Table 5. Liquid low-level waste concentrate (LLLWC) generation during 1992 and 1993

\begin{tabular}{|c|c|c|c|c|}
\hline \multirow[b]{2}{*}{ Generator } & \multicolumn{2}{|c|}{1992} & \multicolumn{2}{|c|}{1993 (expected) } \\
\hline & (gal/year) & (percent) & (gal/year) & (percent) \\
\hline $\begin{array}{l}\text { Process Waste Treatment } \\
\text { Plant }\end{array}$ & 11.500 & 67 & 14.400 & 56 \\
\hline High Flux Isotope Reactor & 2,500 & 15 & 8,200 & 32 \\
\hline $\begin{array}{l}\text { Radiochemical Engineering } \\
\text { Development Center }\end{array}$ & 1,900 & 11 & 2,100 & 8 \\
\hline $\begin{array}{l}\text { Oak Ridge Research } \\
\text { Reactor/Bulk Shielding } \\
\text { Reactor }\end{array}$ & 200 & 1 & 0 & 0 \\
\hline Bldg. 3517 & $<100$ & $<1$ & 0 & 0 \\
\hline Bldg. 3525 & $<100$ & $<1$ & $<250$ & $<1$ \\
\hline Isotopes Area & $<100$ & $<1$ & $<250$ & $<1$ \\
\hline Others & 800 & 5 & $<250$ & 3 \\
\hline Total: & 17.200 & & $26.000^{\circ}$ & \\
\hline
\end{tabular}

•Generator survey estimates were scaled up 30\% to account for greater-than-average generation of LLLWC during CY 1993. 
expected to account for $56 \%$, HFIR for $32 \%$, REDC for $8 \%$, and all others for $<6 \%$ of the LLLWC generation.

\subsubsection{Future LLLWC Generation}

Table 6 lists the predicted LLLWC generation rates for 1994-2010. These generation rates are calculated based on the increase or decrease in dilute LLLW generation rates expected and, if known, changes in the concentrations of other contaminants, acids, bases, salts, and cleaners added to the LLLW by the various generators. However, in most cases, the current VRFs (calculated for the various facilities based on current LLLW characteristics) are used along with the estimated future dilute LLLW generations to give future LLLWC volumes. These LLLWC volumes are used to determine the storage space needed over the next 15 years. The following is a summary of changes which will affect the volume of LLLWC generated over the given time frame:

(1) The PWTP upgrade, due to be completed in 1995, will result in an overall reduction of LLLWC for this facility of approximately 2700 gal/year. A holding tank will be installed to enable the treatment of the entire PWTP LLLW stream by the PWTP evaporator. Currently, a portion of the PWTP stream is evaporated at the LLLW Evaporator Facility, which is less efficient than the PWTP evaporator. Beginning in 2003, the new PWTP will be in operation. The new ion exchange (IX) columns will use nonregenerable IX material which will be disposed of as a solid waste, thus eliminating LLLWC generation at the PWTP entirely. This upgrade is expected to decrease the overall production of solid LLW at the PWTP by about $40 \mathrm{~m}^{3}\left(1400 \mathrm{ft}^{3}\right)$ because of the change in the type of resin used. 
Table 6. Forecasted liquid low level waste concentrate (LLLW) generation, $1994-2010$

\begin{tabular}{|c|c|c|c|c|c|c|c|c|c|c|c|c|c|c|c|c|c|}
\hline \multirow[b]{2}{*}{ Genentor } & \multicolumn{17}{|c|}{ 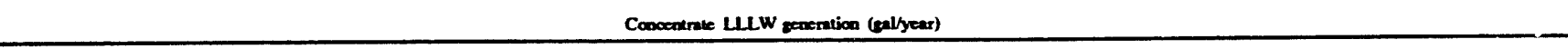 } \\
\hline & 1994 & 1995 & 1996 & 1997 & 1998 & 1999 & 2000 & 2001 & 2002 & 2003 & 2004 & 2005 & 2006 & 2007 & 2008 & 2009 & 2010 \\
\hline Proceses Weste Tresument Plant & 11,100 & 8,400 & 8,400 & 8.400 & 8,400 & 8.400 & 8.400 & 8,400 & 8.400 & 0 & 0 & 0 & 0 & - & 0 & - & o \\
\hline diech Flux bolope Reactor & 5,500 & 5,500 & 3,500 & 5,500 & 0 & 0 & 0 & o & o & 0 & o & 0 & 0 & o & o & 0 & $\mathbf{0}$ \\
\hline $\begin{array}{l}\text { Redioctremical Eneinoerine } \\
\text { Development Center }\end{array}$ & 1,700 & 1,700 & 1,700 & 1,700 & 1.700 & 1,700 & 1,700 & 1,700 & 1,700 & 1,700 & 1,700 & 1.700 & 1,700 & 1,700 & 1,700 & 1.700 & 1,700 \\
\hline Bddz. 3517 & $<100$ & $<100$ & $<100$ & $<100$ & $\infty 0$ & 600 & $\infty 00$ & 600 & 0 & o & 0 & 0 & 0 & - & - & 0 & o \\
\hline Bldz. 3525 & $<100$ & $<100$ & $<100$ & $<100$ & $<100$ & 100 & 100 & $<100$ & $<100$ & $<100$ & 100 & 100 & 100 & $<100$ & 100 & 100 & $<100$ \\
\hline bolopes Area & $<100$ & $<100$ & $<100$ & $<100$ & 300 & 300 & 300 & 300 & $<100$ & $<100$ & 100 & 100 & 100 & 100 & 100 & 100 & $<100$ \\
\hline Othen & 600 & 600 & 500 & 600 & 600 & 450 & 450 & 450 & 600 & 600 & 600 & $\infty 00$ & 600 & $\infty$ & $\infty$ & 600 & 600 \\
\hline Sublotai, generalors: & 19,100 & 16,400 & 16,400 & 16,500 & 11,700 & 11,55 & 11.55 & 11.550 & 10,900 & 2,500 & 2,500 & 2,560 & 2.500 & 2,500 & 2500 & 2.500 & 2,500 \\
\hline Sublotal, $+30 \%$ contingency: & 20,900 & 21,400 & 21,300 & $21, \infty 6$ & 15,200 & 15,00 & 15,0 & 15,000 & 14,200 & 3,300 & 3,300 & 3,360 & 3,360 & 3,300 & 3,300 & 3,300 & 3,360 \\
\hline \multicolumn{18}{|l|}{ Inective Tanb: } \\
\hline liquid & 3,900 & o & o & 15,700 & 9,800 & o & o & 0 & - & 0 & 0 & 0 & 0 & 0 & - & - & - \\
\hline 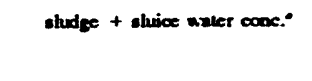 & 0 & $15,700^{\circ}$ & 0 & 0 & 0 & $\begin{array}{r}10,60 \\
0\end{array}$ & 6,800 & 11.100 & 8,300 & 9,800 & 900 & 3,500 & 2,000 & 0 & 0 & 0 & $\mathbf{0}$ \\
\hline $\begin{array}{l}\text { Decondemination and } \\
\text { Decommiesioning }\end{array}$ & 100 & 0 & 200 & 800 & 1.100 & 1,600 & 1,300 & 2,600 & 1,500 & 1,500 & 1,300 & 2,800 & 2.800 & 2,800 & 1,500 & 1,500 & 1.600 \\
\hline Remodiel Actions & 2,200 & 2,600 & 2,600 & 3,400 & 2,100 & 2,200 & 2.300 & 2,200 & 900 & 900 & 1,200 & 1.000 & 700 & 700 & $x 00$ & 700 & 500 \\
\hline Tolat: & 31,100 & 39,700 & 20,300 & 41,360 & 28,200 & 29,40 & $\begin{array}{r}25,30 \\
\bullet\end{array}$ & 30,900 & 24,200 & 15,500 & 6.700 & 10,60 & 800 & 6,800 & 5,500 & 5,500 & 5,400 \\
\hline
\end{tabular}

a The volume generated is sludge volume plus the remaining sluice water concentrate (after settling and evaporation). This is one scenario; it is possible that the

tank sludges will be solidified in place and no sludge or sluice water concentrate will be generated.

- Active tank W-22 sludge is sluiced into the Melton Valley Storage Tanks. 
(2) HFIR will dispose of loaded IX resin as solid waste in the near future. This will eliminate LLLWC from this facility in 1997; the rate of solid LLW generated is expected to be approximately $10 \mathrm{~m}^{3}\left(35 \mathrm{ft}^{3}\right) .^{3}$

(3) Building 3517, after the ISP has been effectively carried out, will not generate LLLWC.

The remaining generators have been estimated to continue production of dilute and concentrated LLLW at the current rates.

LLLWC generation is expected to vary greatly in the next 15 years, depending on the time frame for and extent of the remediation of the inactive tanks (liquids and sludges), Surplus Facility Program D\&D activities, and RA activities. Estimates for the volumes of LLLWC to be generated by these programs are given in Table 6 .

Another activity which will generate significant amounts of LLLWC is sludge removal from ESTs and inactive tanks. The current scenario includes the sluicing of sludges in the following ESTs: W-22 during 1995; and C-1, C-2, W-21, and W-23 during 1999 (removal by sluicing). The sluicing of tank W-22 is expected to generate approximately 14,500 gal of LLLWC. Normally, sluicing of a tank will increase the volume of LLLWC to be stored by the amount of sludge plus sluice water concentrate; however, the sluicing of C-1, C-2, W-21, and W-23 will increase the volume of stored LLLWC only by the amount of sluice water concentrate because the sludge volumes are already included as part of the total cumulative LLLWC volumes. The amount of water needed for sluicing a given amount of sludge was estimated as 3 times the volume of the sludge. ${ }^{4}$ The sluice water can then be evaporated after the sludge has settled, thus leaving a lower volume of "sluice water concentrate." The sludges and sluice water volumes of the inactive tanks are included in the forecasted dilute and concentrated LLLW, beginning in 1999 through 2006. 


\subsection{STORAGE OF LLLWC}

Table 7 lists the LLLWC generations for 1990-2010 and the cumulative storage volumes during that time for various scenarios. Several options are being implemented to provide additional storage space in the MVSTs; a solidification campaign (SC) during the fall of 1993 is planned which will free almost 50,000 gallons of space, and ITE is evaporating an estimated $18,000 \mathrm{gal} / \mathrm{year}$ of water from the MVSTs. (From June 1992 to June 1993, 21,700 gal of water were evaporated from the MVSTs by ITE.) The effects on the cumulative volume of LLLWC with ITE, out-of-tank evaporation (OTE, a proposed activity in which the waste in the MVSTs is removed, evaporated further by an evaporator, and then returned to the tanks), and SCs implemented are given in Table 7. These volumes are shown graphically in Fig. 2 and 3.

Based on the current scenario, assumptions of which are summarized in Fig. 2, an additional SC (past the 1993 campaign) or OTE will be necessary to maintain the LLLWC cumulative volume below the "operationally constrained region" (under 470,000 gal) through 1998. If no inactive tanks or ESTs are emptied before 1998, the cumulative LLLWC volume at the end of the year (1998) would be about 450,000 gal according to current estimates.

Three new 100,000-gal storage tanks will be available in 1998 (Phase I) and three more after 1999 (Phase II), according to the current strategy plans. Figure 3 shows the storage space increase in the Operation Safety Report (OSR) limit with the addition of these tanks. The first phase adds three 100,000-gal tanks in 1998, and the OSR is raised to 720,000 gal (a total space of 900,000 gal less one empty 100,000-gal tank, and $90 \%$ capacity per the OSR). The second phase adds 3 more 100,000-gal tanks, and the OSR is raised to 810,000 gal. The limit is adjusted by removing C-1 and C-2 from service, emptying W-21 (because the 
Table 7. Profile of liquid low-level waste concentrate (LLLWC) storage needs and uses through 2010

\begin{tabular}{|c|c|c|c|c|c|c|c|c|c|c|}
\hline \multirow{2}{*}{$\begin{array}{l}\text { End of } \\
\text { year }\end{array}$} & \multirow{2}{*}{$\begin{array}{c}\text { Concentrate } \\
\text { (gal/year) }\end{array}$} & \multirow{2}{*}{$\begin{array}{c}\text { Sluice } \\
\text { whter evap. } \\
\text { (galyear) }\end{array}$} & \multirow{2}{*}{$\begin{array}{l}\text { Volume } \\
\text { eolidified } \\
\text { (gal/year) }\end{array}$} & \multirow{2}{*}{$\begin{array}{c}\text { OTE } \\
\text { volume evap. } \\
\text { (galyear) }\end{array}$} & \multicolumn{2}{|c|}{ ITE volume evaporated } & \multicolumn{4}{|c|}{ Cumulative stored volume of LLWC (gal) } \\
\hline & & & & & $\begin{array}{c}\text { withoun OTE } \\
\text { (ealyear) }\end{array}$ & $\begin{array}{l}\text { with OTE } \\
\text { (gallyear) }\end{array}$ & & with ITE & $\begin{array}{l}\text { with } \\
\text { ITE \& SC }\end{array}$ & $\begin{array}{l}\text { with ITE. } \\
\text { SC \& OTE }\end{array}$ \\
\hline $1990^{\circ}$ & 16,140 & $\mathbf{0}$ & $\mathbf{0}$ & 0 & 0 & 0 & 474.650 & 474,650 & 474.650 & 474,650 \\
\hline 1991 & 22,052 & $\mathbf{0}$ & 27.960 & $\mathbf{0}$ & $\mathbf{0}$ & 0 & 460,500 & 460,500 & 460.500 & 460,500 \\
\hline 1992 & 17,263 & 0 & 18,940 & $\mathbf{0}$ & 15,501 & 15,501 & 443,930 & 443.930 & 443,930 & 443,930 \\
\hline $1993 \mathrm{~K}$ & 39,600 & 0 & 20,000 & 0 & 18,000 & 18,000 & 483,530 & 465,530 & 415.530 & 415,530 \\
\hline 1994 & 31.100 & 0 & 30,000 & 20,000 & 18,000 & 18.000 & 514,630 & 478.630 & 428.630 & 408.630 \\
\hline 1995 & 39.700 & 42,400 & 0 & 30,000 & 18,000 & 18,000 & 554.330 & 500,330 & 450,330 & 400,330 \\
\hline 1996 & 24,300 & 0 & 0 & 0 & 18,000 & 6.363 & 578.630 & 506.630 & 456.630 & 418,267 \\
\hline 1997 & 41,300 & 0 & 0 & 0 & 18,000 & 10,017 & 619.930 & 529.930 & 479.930 & 449,549 \\
\hline 1998 & 28,200 & o & 0 & 0 & 9.216 & 9.216 & 648,130 & 548,914 & 498,914 & 468,533 \\
\hline 1999 & 29.400 & 154,400 & 0 & 0 & 4,457 & 4.457 & 677.530 & 573.856 & 523,856 & 493,475 \\
\hline 2000 & 25.300 & 18.400 & 0 & 0 & 18,000 & 18,000 & 702,830 & 581,156 & 531,156 & 500,775 \\
\hline 2001 & 30,900 & 30,000 & 0 & 0 & 4.609 & 4,609 & 733.730 & 607.448 & 557.448 & 527,067 \\
\hline 2002 & 24.900 & 22,600 & 0 & 0 & 4,464 & 4,464 & 758.630 & 627.884 & 577,884 & 547,503 \\
\hline 2003 & 15,500 & 26,500 & o & 0 & 1,127 & 1.127 & 774,130 & 642.257 & 592.257 & 561,876 \\
\hline 2004 & 6,700 & 2.400 & 0 & 0 & 1,159 & 1.159 & 780,830 & 647.798 & 597,798 & 567,418 \\
\hline 2005 & 10,600 & 9.400 & o & 0 & 961 & 961 & 791.430 & 657.438 & 607.438 & 577.057 \\
\hline 2006 & 8.800 & 5,300 & 0 & 0 & 1,019 & 1,019 & 800,230 & 665,219 & 615.219 & 584,838 \\
\hline 2007 & 6.800 & 0 & o & 0 & 985 & 985 & 807,030 & 671.034 & 621,034 & 590.653 \\
\hline 2008 & 5,500 & 0 & 0 & 0 & 941 & 941 & 812,530 & 675.593 & 625,593 & 595.212 \\
\hline 2009 & 5.500 & 0 & 0 & 0 & 941 & 941 & 818,030 & 680,151 & 630.151 & 599,771 \\
\hline 2010 & 5.400 & 0 & o & 0 & 941 & 941 & 823,430 & 684,610 & 634,610 & 604.229 \\
\hline
\end{tabular}

OTE = out-of-tank evaporation; ITE = in-tank evaporation; SC = solidification campaign.

${ }^{a}$ An additional SC would have the same effect as OTE on stored volumes of LLLWC in this analysis.

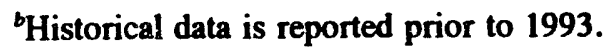

Includes a 15,300 gal addition to the concentrate generation to account for change in level instrumentation; 1993 through

2010 is projected data. 


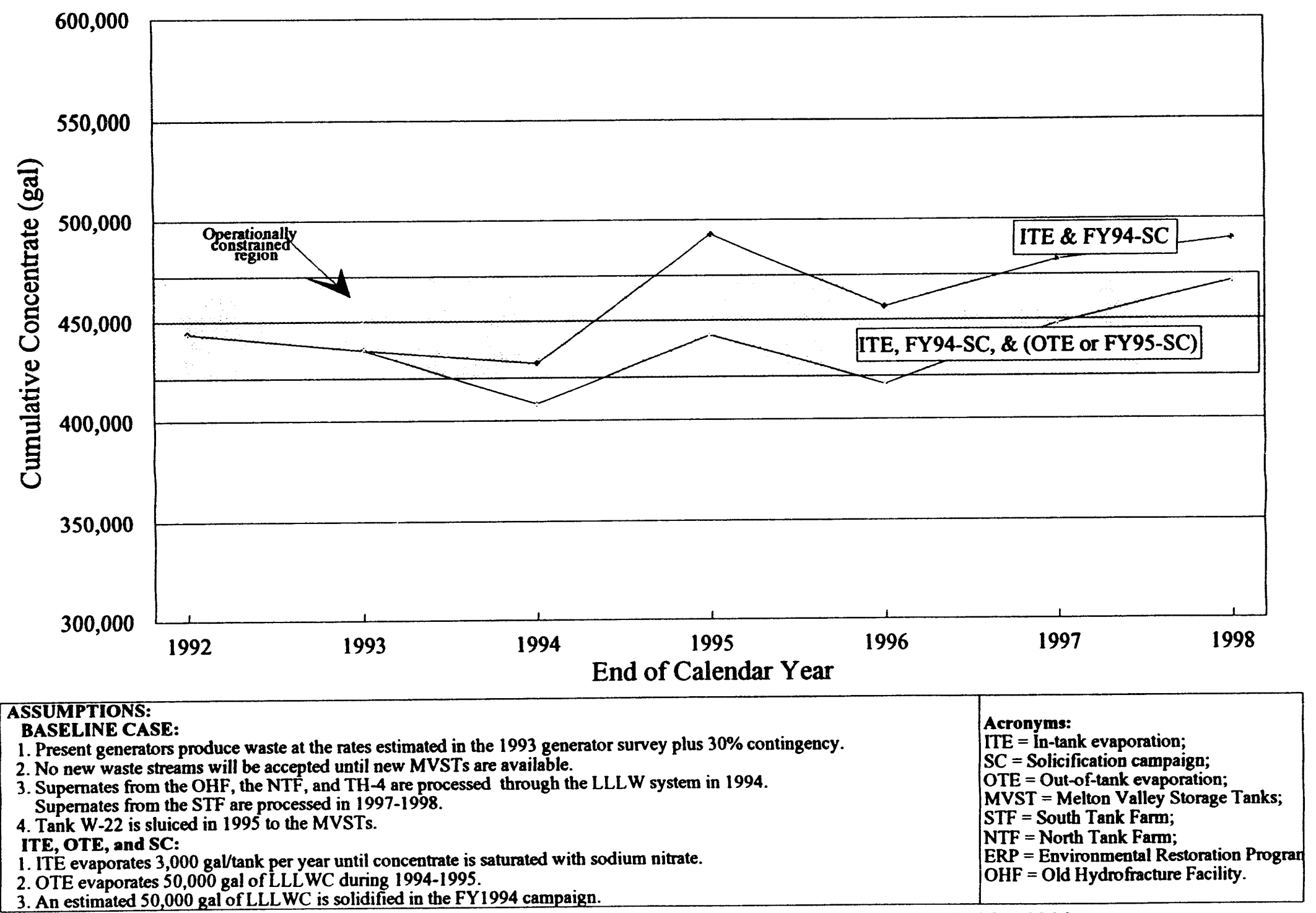

Fig. 2. Liquid low-level waste concentrate (LLLWC) generation, 1992 - 1998. 


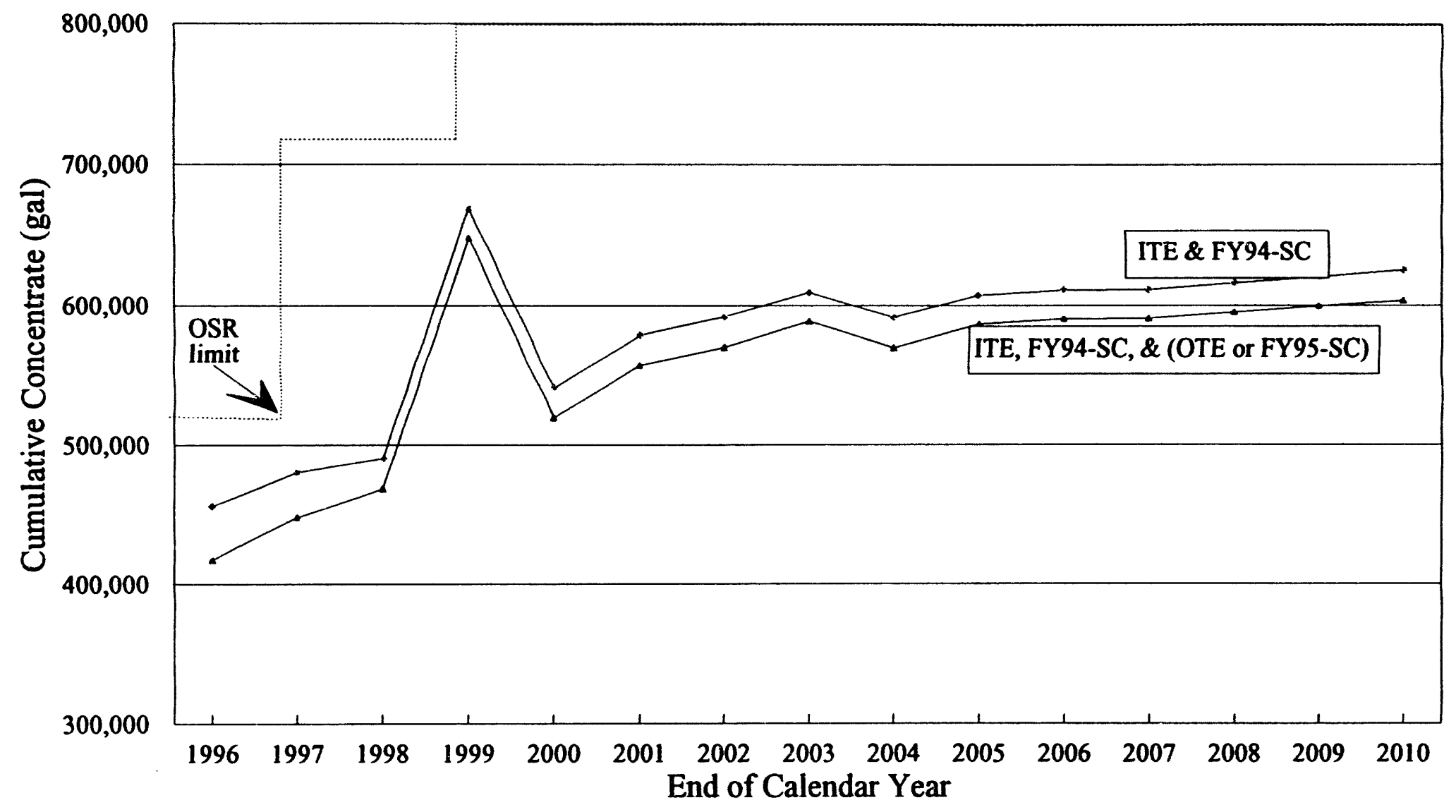

\section{ASSUMPTIONS:}

\section{BASELINE CASE:}

1. Present generators produce waste at the rates estimated in the 1993 generator survey plus $30 \%$ contingency.

2. No new waste streams will be accepted until new MVSTs are available.

3. Supernates from the OHF, the NTF, and TH-4 are processed through the LLLW system in 1994.

Supernates from the STF are processed in 1997-1998.

Supernates from the STF are processed in $1997-$
4. Tank W-22 is sluiced in 1995 to the MVSTs.

4. Tank W-22 is sluiced
ITE, OTE, and SC:

1. ITE evaporates $3,000 \mathrm{gal} /$ tank per year until concentrate is saturated with sodium nitrate.

2. OTE evaporates $50,000 \mathrm{gal}$ of LLLWC during 1994-1995.

3. An estimated 50,000 gal of LLLWC is solidified in the FY 1994 campaign.

Acronyms:

ITE = In-tank evaporation;

SC = Solicification campaign;

OTE = Out-of-tank evaporation

MVST = Melton Valley Storage Tanks;

STF = South Tank Farm;

STF $=$ South Tank Farm;
NTF $=$ North Tank Farm;

ERP = Environmental Restoration Progra $\mathrm{OHF}=$ Old Hydrofracture Facility

Fig. 3. Liquid low-level waste concentrate (LLLWC) generation, 1996 - 2010. 
tank will be used only as an LLLW feed tank), and emptying W-23 to allow for segregation of waste. This reduces the total capacity by 200,000 gal; a reduction in capacity of only 100,000-gal would be seen if C-1 and C-2 were kept in service. Current plans are to keep tanks C-1 and C-2 in service; however, in the past, the removal of these tanks from service has been discussed. Should the tanks remain in service, the OSR limit would be 900,000 gal.

Fig. 4 depicts the concentrate storage situation for 1996 through 2010 under the following scenario:

(a) the only solidification campaign is the one scheduled during FY94;

(b) ITE is discontinued when the new tanks are completed (1997);

(c) the HFIR continues to produce LLLW through this time period (1997-2010);

(d) the PWTP upgrade is terminated, and LLLWC continues to be generated through 2010 at this facility.

This scenario, shown in Fig. 4, is the most conservative view of the LLLWC storage situation over the next 15 years, while Fig. 3 graphically illustrates the storage situation assuming ITE continues, the HFIR begins source treatment in 1998, and the PWTP concentrate production ends in 2002. Because of budget uncertainties, either scenario is plausible. Fig. 4 demonstrates the need for a second phase of new tanks, thereby increasing the storage space to an acceptable level.

\section{SUMMARY AND CONCLUSIONS}

Total dilute LLLW generation rates for ORNL have been relatively steady when compared to the previous few years. Most generators have not significantly changed their 1993 waste generation rates over the last year. REDC has reduced the solids content of its LLLW and therefore its resulting concentrate volume. Groundwater and rainwater continue to make up a large portion ( $50 \%)$ of the dilute LLLW generation. HFIR and the PWTP are both 


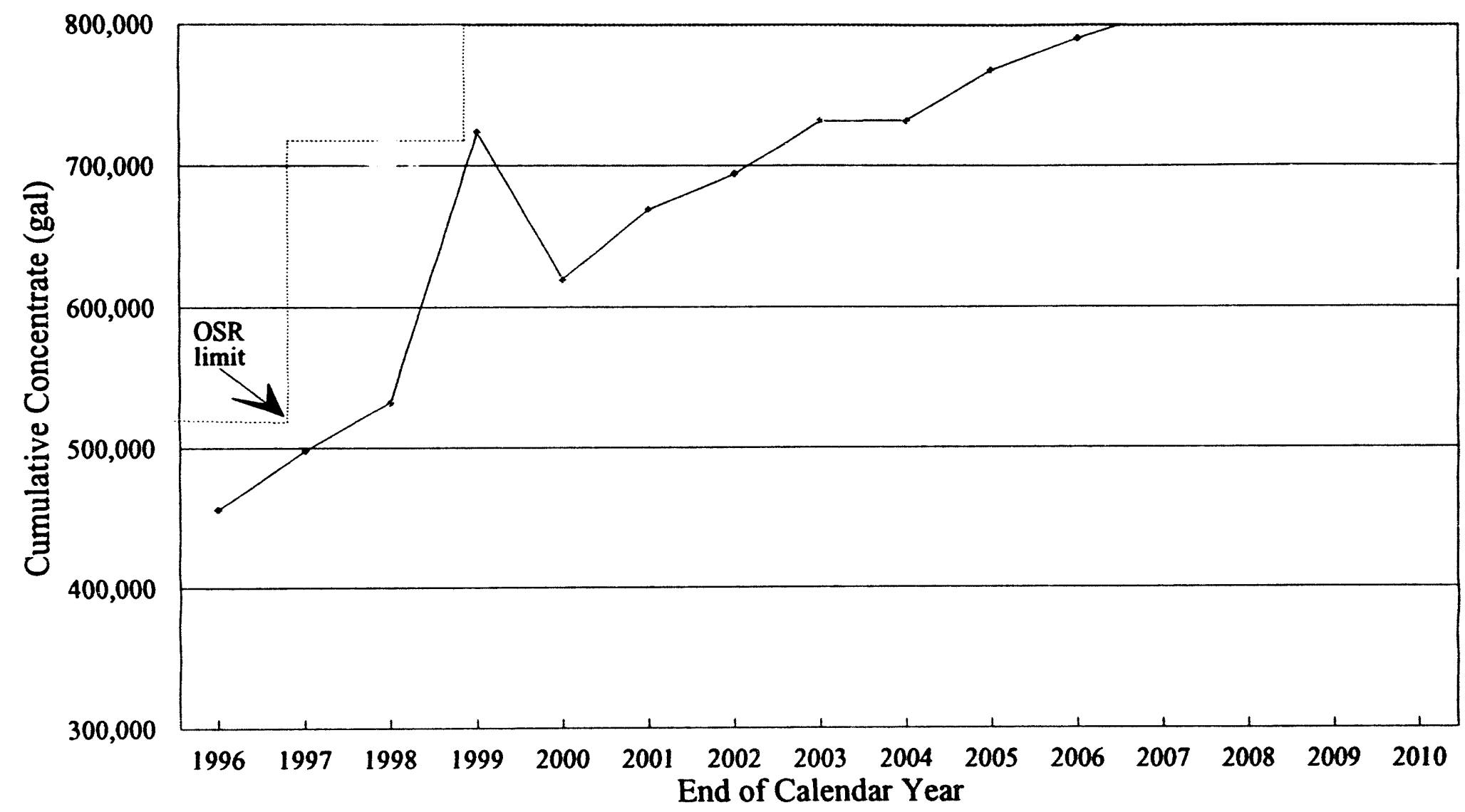

\section{ASSUMPTIONS:}

BASELINE CASE:

1. Present generators produce waste at the rates estimated in the 1993 generator survey plus $30 \%$ contingency.

2. No new waste streams will be accepted until new MVSTs are available.

3. Supernates from the OHF, the NTF, and TH-4 are processed through the LLLW system in 1994.

Supernates from the STF are processed in 1997-1998.

4. Tank W-22 is sluiced in 1995 to the MVSTs.

ITE, SC:

1. ITE evaporates $3,000 \mathrm{gal} /$ tank per year until concentrate is saturated with sodium nitrate and until 1997.

2. One solidification campaign is carried out in FY94.

Acronyms:

ITE = In-tank evaporation;

MVST = Melton Valley Storage Tanks;

STF $=$ South Tank Farm;

STF $=$ South Tank Farm

NTF = North Tank Farm;

$\mathrm{OHF}=$ Old Hydrofracture Facility .

SC=solidification campaign;

PWTP=Process Waste Treatment Plant;

Fig. 4. Liquid low-level waste concentrate (LLLWC) generation, 1996 - 2010 without (a) source treatment at HFIR and

(b) the PWTP upgrade. 
preparing to generate only solid LLW in the next decade. Remediation activities from various programs are expected to begin generating significant amounts of dilute LLLW over the same time frame.

CY 1993 generation rates of LLLWC have increased approximately $30 \%$ over predicted rates based on generator input. Approximately 26,000 gal of LLLWC is expected to be produced by the end of 1993. During 1992, 17,200 gal of LLLWC was produced. The majority of the increase is attributed to operational difficulties at HFIR which have resulted in additional waste generation at that facility. Further explanation for the increase in LLLWC generation during 1993 has not been ascertained. The PWTP continues to be the largest generator of LLLWC (56\%); HFIR generates $32 \%$ of the concentrate, and REDC accounts for $8 \%$ of the concentrate. The PWTP will, most likely, be decoupled from the LLLW system within 10 years, as will HFIR (about 1997). During the next 10-20 years, the Surplus Facilities and RA programs will generate a larger percentage of the concentrate through cleanup activities, such as emptying the inactive tanks.

Assuming the given LLLWC generation rates in Table 6, the continuance of ITE, and the completion of the 1993 SC, the available tank space will remain under the 470,000 -gal limit that Waste Operations personnel have deemed operationally manageable only until early 1997 An additional SC or OTE will be necessary to maintain the free space at 50,000 gal below the OSR limit of $520,000 \mathrm{gal}$ after 1997 . If the current schedule for the new tanks is maintained, additional storage volume for LLLWC should be available by 1998. Although it is conceivable that operation of the LLLW system could continue through this time period (1993-1998) without an additional SC (or OTE), recommendations are to plan an additional SC (or OTE) to accommodate a delay in the installation of new tanks or generation of concentrate above those rates estimated over the next several years. 
Uncertainties in budgets rule the need for the second phase of new concentrate storage tanks. If the HFIR source treatment and the PWTP upgrades are not acquired, a second phase of new storage tanks will be necessary, as seen from Fig. 4 .

This report recommends continuation of projects to develop and implement source treatment at REDC, HFIR, PWTP, and ORR/BSR. These source treatment projects envelop the major generators of LLLWC (approximately $95 \%$ of the LLLWC generation). Reducing the dilute LLLW generation by the major dilute generator - nonprogrammatic waste and infiltration of groundwater - continues to be a topic considered by the FFA team. Appointed team members are responsible for identifying nonprogrammatic areas to be rerouted to the PWTP. Repairs to tanks and reduc ion of input to the LLLW system in any other appropriate manner continue to be tasks followed by the FFA team. 


\section{REFERENCES}

1. L. E. McNeese, J. B. Berry, G. E. Butterworth III, E. D. Collins, T. H. Monk, B. D. Patton, and J. W. Snider, Overall Strategy and Program Plan for Management of Radioactively Contaminated Liquid Wastes and Transuranic Sludges at the Oak Ridge National Laboratory, ORNL/TM-10757, December 1988.

2. T. J. Abraham, S. M. DePaoli, A. B. Walker, and S. M. Robinson, Preliminary Analysis of the ORNL LLLW System, ORNL/TM-11250, in progress.

3. Waste Management and Remedial Action Division, ORNL Waste Management Plan Fiscal Year 1994, ORNL/TM-11433/R3, December 1993.

4. Warren Thompson, personal communication, 1993. 


\section{INTERNAL DISTRIBUTION}

1. T. J. Abraham

2. P. E. Arakawa

3. J. S. Baldwin

4. J. T. Bell

5. S. E. Breeding

6. W. D. Bond

7. C. H. Brown

8. T. W. Burwinkle

9. A. D. Clay

10. E. D. Collins

11. A. G. Croff

12. D. L. Daugherty

13-17. S. M. DePaoli

18. B. Z. Egan

19. J. R. Forgy, Jr.

20. V. L. Fowler

21. W. Fulkerson

22. H. R. Gaddis

23. F. J. Homan

24. J. H. Hooyman

25. R. J. Hydzik
26. L. L. Kaiser

27. C. M. Kendrick

28. T. M. Kent

29. J. L. Maddox

30. C. P. Manrod

31. R. C. Mason

32. L. E. McNeese

33. D. R. McTaggart

34. S. R. Michaud

35. L. B. Oakley

36. J. R. Parrott, Jr.

37. J. J. Perona

38. D. J. Peterson

39. J. H. Platfoot

40. R. E. Pudelek

41. S. M. Robinson

42. S. T. Rudell

43. T. F. Scanlan

44. C. B. Scott

45. R. B. Shelton

46. R. C. Stewart
47. L. E. Stratton

48. P. A. Taylor

49. W. T. Thompson

50. J. R. Trabalka

51. M. W. Tull

52. D. W. Turner

53. J. W. Tumer

54. J. F. Walker

55. G. D. West

56. M. L. Whitehead

57. Central Research Library

58. Document

Reference

Section

59-60. Laboratory Records

61. Laboratory Records, R.C

62. ORNL Patent

Section

EXTERNAL DISTRIBUTION

63. Office of Assistant Manager, Energy Research and Development, DOE-OR, P.O. Box 2001, Oak Ridge, TN 37831

64-65. Office of Scientific and Technical Information, P.O. Box 62, Oak Ridge, TN 37831 


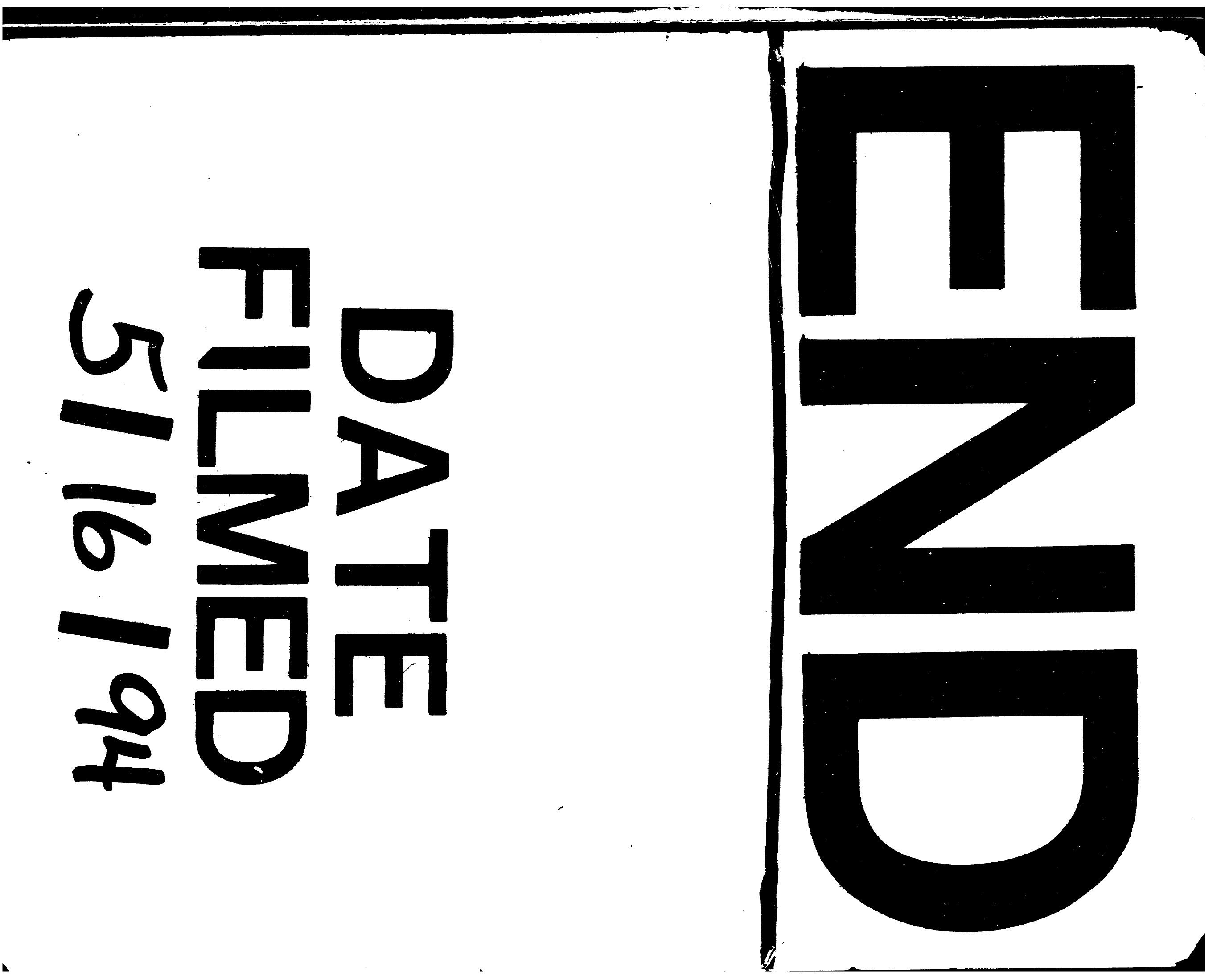


